\title{
Számítási módszer a behajlási teknő megbízható modellezéséhez
}

\section{Zsichla László ${ }^{1}$}

${ }^{1}$ Rodcont kft.

E-mail: rodcont@gmail.com

DOI: $\underline{10.36246 / \text { UL.2021.1.06 }}$

\section{KIVONAT}

Az útpályaszerkezet teherbírásának mérésekor okozott és mért behajlási teknő minél pontosabb modellezése nagy jelentőségü. Megoldatlan probléma a különböző mérési módszerek mérési eredményeinek megbízható átszámíthatósága. A cikkben megoldom a különböző terhelő felületek által okozott, a felültre merőleges összenyomódások analitikus számítását a végtelen féltér bármely pontjában. A bemutatott számítással jól, az eddig ismert módszereknél egy nagyságrenddel pontosabban számítható a behajlási teknő és a kialakuló tényleges feszültség.

Kulcsszavak: feszültségeloszlás, behajlási teknő, útpályaszerkezet méretezése

\section{ABSTRACT}

The most accurate modeling of the deflection basin caused and measured when measuring the bearing capacity of the road structure is essential. It is an unresolved problem to convert the results of different measurement methods reliably. In this paper, I solve the analytical calculation of the compressions perpendicular to the surface caused by different loading surfaces at any point in the infinite half-space. With the presented calculation, the deflection basin and the actual stresses can be calculated more accurately than the previously known methods.

Keywords: stress distribution, deflection basin, road pavement design

\section{Zsichla László}

A Rodcont kft. ügyvezetöje. Kutatási területe, aszfaltkeverékek modifikálása, pályaszerkezetben keletkezö feszültségek modellezése. Fö munkaterülete, burkolattechnológiai szakvélemények készitése úttervezö cégek számára.

\section{BeVEZETÉS, PROBLÉMA FELVETÉSE}

Jelen cikkben a mérnöki gyakorlat számára is kielégítő pontosságú módszert ismertetünk, amelynek segítségével az adott terhelő felület és terhelés által okozott behajlási teknő meghatározható a többrétegü pályaszerkezetben.

A módszer Boussinesqu (1885) által megadott feszültségkomponenseket, és Odemark-Ivanov (1949) által ajánlott helyettesítő rétegvastagságot veszi alapul, amely igen jó közelítés a tényleges behajlási teknő modellezéséhez.

A módszer alkalmazásának előnye, hogy nagyon pontosan meg tudjuk határozni a terheléskor - pl. teherbírás méréskor - az altalaj $E_{2}$ alakváltozási modulusát, amely a mérési módszertől függően lehet dinamikus ill. „kvázi” statikus. 
A következő eredmény, hogy a módszer segítségével a különböző mérési módszerekkel kapott mérési eredmények egymásba átszámíthatókká válnak. Számos nemzetközi és hazai kísérlet történt [1] a párhuzamos összehasonlításon alapuló összefüggések feltárására, de a vizsgálatok, elemzések nem hoztak kielégítő eredményt a viszonylag alacsony regresszió miatt COST 324 [2].

A harmadik eredmény, hogy viszonylag jól modellezhetővé váltak a pályaszerkezeti rétegek állapotában történő változások hatására a behajlási teknő és evvel összefüggésben a ténylegesen kialakuló feszültségek.

Magyarországon a pályaszerkezet méretezésének módszertana az elmúlt harminc évben szinte semmit sem fejlődött, vannak ugyan bíztató kísérletek egy korszerü méretezési módszer bevezetésére [3], de még nagyon messze vagyunk az AASHTO-féle MEPDG módszerektől [4]. Az utak várható élettartamára vonatkozó hazai kutatás számos eredményről számolhat be [5], aminek csak egy kis szelete jelenlegi témánk, ennek ellenére a hazai tervezési gyakorlatban ebböl nagyon kevés, pazarlóan kevés hasznosul.

A jelenlegi méretezési módszerben keveredik a statikus és a dinamikus alakváltozási modulus, eltér a méréskori hőmérséklet $20{ }^{\circ} \mathrm{C}$ és a méretezéskori aszfalt hőmérséklet $5{ }^{\circ} \mathrm{C}$, ami a méretezéskor nincs figyelembe véve. Probléma az évszaki szorzók használata, amely nagyon elnagyoltan és pontatlanul veszi figyelembe a méréskori altalaj teherbírását.

További gond, hogy a teherbírás mérése sokszor a dinamikus KUAB eredményeit „számítja” át statikus behajlásokra. Az átszámítás szükséges, hiszen az élettartam görbék a BB Benkelman tartós mérésen alapulnak, de a megadott átszámítás nagyon pontatlan.

Még megemlítjük a méréskori aszfalt hőmérsékletét is, amelynek felületi hőmérsékletét pontosan mérjük, de az aszfalt pályaszerkezeten belüli hőmérséklet eloszlást nem ismerjük. Azt egyértelmüen kijelenhetjük, hogy a burkolat felületén mért hőmérséklet jelentősen eltér az aszfalt pályaszerkezet átlagos hőmérsékletétől. Az eltérő hőmérséklet pályaszerkezeten belül eltérő alakváltozási modulussal jár, ezért a méréskori pályaszerkezeten belüli hőmérséklet eloszlás viszonylag pontos becslése is szükséges. A cikknek nem tárgya, de a pályaszerkezeten belüli hőmérséklet becslésénél figyelembe kell venni a napi átlag hömérsékletet is. Nem mindegy, hogy március közepén napsütésben mérünk a burkolat felületén $20^{\circ} \mathrm{C}$-ot, amikor a napi átlag hömérséklet $8{ }^{\circ} \mathrm{C}$ volt, vagy július közepén mérünk borult időben $20^{\circ} \mathrm{C}$-ot, amikor a napi átlag hőmérséklet $22^{\circ} \mathrm{C}$ volt.

Egyetértve Dr. Nemedy Ervinnel [6] az útpályaszerkezet tényleges viselkedését csak nagyon közelítően modellezhetjük, ahol viselkedésen a pályaszerkezet élettartama alatti viselkedést értjük. A szükségszerü bizonytalanságot azonban a mechanikailag megalapozottabb méretezési módszerrel csökkenthetjük.

Jelenleg nem feltünőek a méretezési eljárás ellentmondásai, olyan ez, mint amikor a viharhullámok cunamival párosulnak, ezért a viharhullámokat már elhanyagoljuk.

\section{SZÁMÍTÁSI MÓDSZER BEMUTATÁSA}

A mért behajlások, behajlási teknők számítására már korábban tettem javaslatot [7] [8], most azonban az elmúlt harminc év szakértői gyakorlatát is felhasználva teszem közzé.

A $2 *$ r átmérőjü tárcsán egyenletesen megoszló terhelés alatt a tárcsa tengelyében $\mathrm{m}=2$ harántkontrakció esetén a Boussinesq-féle feszültségkomponenseknek van zárt alakban integrálható megoldása. Más esetekre vonatkozó integrálás nem volt ismert, ezért volt szükség egy általános megoldásra, amit most részletesen ismertetek.

A homogén és izotrop féltér felszínén müködő koncentrált erő által keltett feszültségeket (1.sz. ábra) Boussinesq által megadott feszültségkomponensekkel (1-4) tudjuk meghatározni. 
$\sigma_{\mathrm{Z}}=\frac{3 * \mathrm{P} * \mathrm{Z}^{3}}{2 * \pi * \mathrm{R}^{5}}$

$\sigma_{\mathrm{r}}=\frac{\mathrm{P}}{2 * \pi * \mathrm{Z}^{2}} *\left\lfloor 3 * \cos ^{3} \alpha * \sin ^{2} \alpha-\left(\frac{\mathrm{m}-2}{\mathrm{~m}} * \frac{\cos ^{2} \alpha}{1+\cos \alpha}\right)\right\rfloor$

$\sigma_{\alpha}=\frac{\mathrm{P}}{2 * \pi * \mathrm{Z}^{2}} * \frac{\mathrm{m}-2}{\mathrm{~m}} *\left(\cos ^{3} \alpha-\frac{\cos ^{2} \alpha}{1+\cos \alpha}\right)$

$\tau_{\mathrm{r}, \mathrm{Z}}=\frac{\mathrm{P}}{2 * \pi * \mathrm{Z}^{2}} * \cos ^{4} \alpha * \sin \alpha$

$m=1-\mu$

$\mu$ - Poisson szám

$\mathrm{R}=\sqrt[2]{\left(z^{2}-r^{2}\right)}$

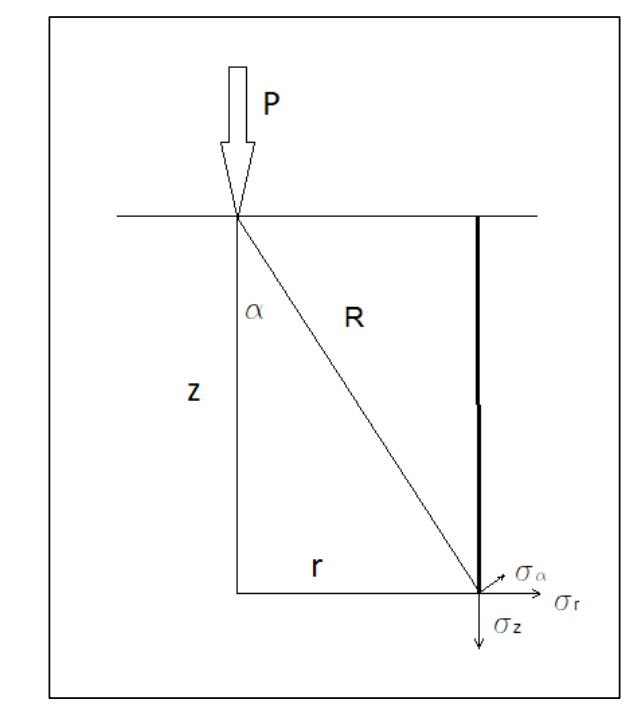

1.ábra: P koncentrált erő által okozott feszültségek értelmezése $r$ távolságban és z mélységben egy tetszőlegesen felvett tengelyen.

$\mathrm{r}$ - a P koncentrált erőtől mért távolság

$\mathrm{Z}$ - a vizsgált pontban a mélység a felszínre merőlegesen mérve.

A féltéren egy tetszőleges $\mathrm{x}, \mathrm{y}$ pontban lévő tengelyben felvett hengeres elem $\mathrm{z}$ tengely irányú $0-Z$ mélységig terjedő összenyomódása:

$\mathrm{S}_{0-\mathrm{Z}}=\frac{1}{\mathrm{E}} * \int_{0}^{\mathrm{z}}(\sigma \mathrm{z}-\mu *(\sigma \mathrm{r}+\sigma \alpha)) \mathrm{dz}$

E - a homogén és izotróp féltér rugalmassági modulusa.

Itt nagyon fontos megjegyezni, hogy általában nem rugalmassági, hanem alakváltozási modulussal számolunk, mert az útpályaszerkezet anyaga adott feszültség mellett mindig tartalmaz maradó és rugalmas alakváltozást. Amikor alakváltozási modulussal számolunk, elvileg nem tehetnénk meg, hogy az E értékét kiemeljük, hanem minden egyes feszültség értéket el kellene osztani az adott feszültséghez tartozó Ei értékkel. Ha ezt nem tesszük, márpedig ezt nem tesszük meg, ebben az esetben feltételezzük, hogy a vizsgált feszültség tartományban az E értéke állandó és ezen belül állandó a maradó és a rugalmas alakváltozás aránya is. Általában ez a feltételezés megfelelő, de vannak esetek, amikor ez a kitétel nem tartható, pl. merev terhelő tárcsák szélénél, ill. ha a vizsgált anyag törőszilárdságának, aszfaltok esetén, $70 \%$-át meghaladó mértékủ a feszültség.

Az integrálást tagonként paraméteres integrálással tudjuk megoldani, ahol a paraméter

$Z=r^{*} \operatorname{ctg} \alpha \quad Z$ deriváltja, $Z^{\prime}=(-) r^{*} \frac{1}{\sin ^{2} \alpha}$

A teljes z tengely irányú összenyomódás a tetszőlegesen felvett pontban:

$\mathrm{S}_{\mathrm{u}}=\frac{\mathrm{P}}{\mathrm{r} * \pi * \mathrm{E}} *\left(1-\mu^{2}\right)$

A z tengely irányú összenyomódás a tetszőlegesen felvett pontban $\mathrm{Z}$ mélység alatt:

$\mathrm{S}_{\mathrm{z}-\infty}=\frac{\mathrm{P}}{2 * \mathrm{r} * \pi * \mathrm{E}} *\left|3 *\left\{\frac{\mathrm{r}}{\mathrm{R}}-\frac{1}{3}\left(\frac{\mathrm{r}}{\mathrm{R}}\right)^{3}\right\}-\mu *\left\{\left(\frac{\mathrm{r}}{\mathrm{R}}\right)^{3}+(1-2 * \mu) *\left(\frac{\mathrm{r}}{\mathrm{R}}+2 * \frac{\mathrm{z}-\mathrm{R}}{\mathrm{r}}\right)\right\}\right|$

Könnyen belátható, hogy $\mathrm{Z}=0$ esetben $\mathrm{r}=\mathrm{R}$, és $\mathbf{S}_{0-\mathrm{z}}=\mathbf{S}_{\mathrm{u}}$.

$\mathrm{S}_{0-z}=\mathrm{S}_{\mathrm{u}}-\mathrm{S}_{\mathrm{z}-\infty}$ 
Rétegzett pályaszerkezet esetén, a behajlási teknő számításához a terhelés tengelyétől mért $r$ távolságban keletkezett teljes összenyomódásra van szükségünk. A rétegek eltérő alakváltozási modulusa miatt, rétegenként kell meghatározni az összenyomódás értékét. A rétegenkénti

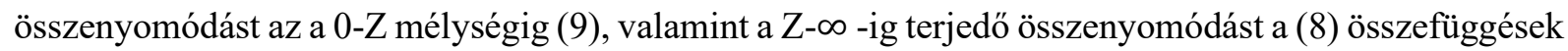
segítségével számítjuk.

Az útpályaszerkezetet terhelése nem egy koncentrált erő általi, hanem egy meghatározott felületen eloszló nyomás, amely a legritkább esetben egyenletesen megoszló, hanem attól eltérő eloszlású. Ezt a feszültség eloszlást közelítjük véges számú koncentrált erővel.

Az egyenletesen megoszló terhelést az $\mathrm{F}$ nagyságú felületre jutó $\mathrm{P}$ terhelésből $\mathrm{p}=\frac{P}{F}$ közismert összefüggésből kapjuk. Ha egy tetszőleges $\mathrm{F}$ nagyságú felületet $\mathrm{n}$ véges számú részre osztunk és minden egyes részre $\frac{P}{n}$ koncentrált erőt helyezünk, akkor evvel modellezhetjük az $\mathrm{F}$ felületen egyenletesen megoszló terhelést, ahol $\mathrm{p}=\frac{P}{n}$.

Ekkor ugyanis a P/n nagyságú koncentrált erő F/n felületen oszlik el (2.sz. ábra).

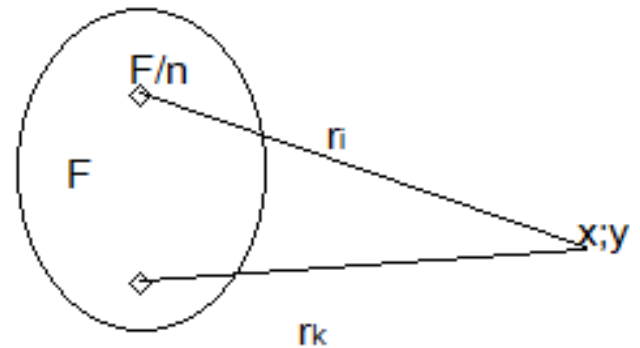

2. ábra: Véges számú $F / n$ felületen eloszló és $P / n$ nagyságú koncentrált erő $r_{i}$ távolsága egy tetszőlegesen felvett ponttól.

Az $\mathrm{F}$ felületen egyenletesen elosztott $\mathrm{n}$ darab $\mathrm{P} / \mathrm{n}$ nagyságú erő által okozott $\mathrm{z}$ tengely irányú összenyomódást mindig egy általunk, vagy egy mérőeszköz által mért rögzített $\mathrm{x} ; \mathrm{y}$ pontban kell számolni. Mérőeszköz által megadott pontok pl. KUAB esetén, ha az origó a tárcsa tengelye, akkor hengerkoordináta rendszerben a mérés tengelyétől számított $0 ; 200 ; 300 ; 450 ; 600 ; 900 ; 1200 ; 1500$; 1800 milliméter távolságban lévő pontok, ahol az összenyomódás mérések történnek.

Lacroix és BB mérések esetén az origót a terhelő iker kerekek szimmetria tengelyében célszerü felvenni és derékszögü koordináta rendszer alkalmazása célszerü a mérőpont és a $\mathrm{P}_{\mathrm{i}}$ koncentrált erő helyek közötti $r_{i}$ távolságok számítására.

A számítási módszer szempontjából lényegtelen, hogy az $\mathrm{r}_{\mathrm{i}}$ távolságok számítása milyen koordináta rendszerben történik.

Egy tetszőlegesen felvett $\mathrm{x}$; $\mathrm{y}$ pontban az F felületen ható $\mathrm{n}$ darab $\frac{P}{n}$ koncentrált erő okozta teljes (4) ill. 0-Z mélység (9) közötti összenyomódást az az $\mathrm{r}_{\mathrm{i}}$ változó távolságra lévő koncentrált erők által okozottösszenyomódások összegzésével kaphatjuk.

$$
\begin{aligned}
& \mathrm{U}_{\mathrm{u}}=\sum_{\mathrm{i}}^{\mathrm{n}}\left(1-\mu^{2}\right) \frac{\mathrm{P}}{\mathrm{n} * \mathrm{ri} * \pi * \mathrm{E}} \\
& \mathrm{U}_{\mathrm{z}-\infty}=\sum_{\mathrm{i}}^{\mathrm{n}} \frac{\mathrm{P}}{2 * \mathrm{n} * \mathrm{ri} * \pi * \mathrm{E}} *\left|3 *\left\{\frac{\mathrm{ri}}{\mathrm{Ri}}-\frac{1}{3}\left(\frac{\mathrm{ri}}{\mathrm{Ri}}\right)^{3}\right\}-\mu *\left\{\left(\frac{\mathrm{ri}}{\mathrm{Ri}}\right)^{3}+(1-2 * \mu) *\left(\frac{\mathrm{ri}}{\mathrm{Ri}}+2 * \frac{\mathrm{zi}-\mathrm{Ri}}{\mathrm{ri}}\right)\right\}\right| \\
& \mathrm{R}_{\mathrm{i}}=\sqrt[2]{\left(\mathrm{zi}^{2}-\mathrm{ri}^{2}\right)}
\end{aligned}
$$

Ha az F felületen belül vesszük fel az x;y pontot, akkor az x;y pont szükségszerüen valamelyik F/n méretü felületre kerül. Ebben az esetben szükségszerü, hogy ri 0 közelében az összenyomódások (7) és (8) a végtelenhez tartanak.

Ebben az esetben az $r i$ értékét $\mathrm{x} / 2$-re vesszük fel, ahol $\mathrm{x}=\sqrt{\frac{F}{n}}$ 
Itt kihasználtuk azt a hasonlóságot, hogy egy $\mathrm{r} / 2$ távolságban elhelyezett $\mathrm{P}$ koncentrált erő ugyanakkora összenyomódást okoz r/2 távolságban, mint egy $r$ sugarú tárcsán egyenletesen megoszló terhelés a tárcsa tengelyében okozott süllyedés, amelynek közismert képlete:

$\mathrm{S}=\frac{2 * \mathrm{r} * \mathrm{p}}{\mathrm{E}} *\left(1-\mu^{2}\right)=\frac{2 * \mathrm{P}}{\mathrm{r} * \pi * \mathrm{E}} *\left(1-\mu^{2}\right)$

Ahol:

$\mathrm{p}=\frac{\mathrm{P}}{\mathrm{F}}$, és $\mathrm{F}=\mathrm{r}^{2 *} \pi$

S süllyedés (12), akkor lesz egyenlő a (7) $S_{u}$ koncencentrált erő által okozott süllyedéssel, ha a koncentrált erő a vizsgált $r / 2$ távolságra van, ahol $r$ a tárcsa sugara.

Természetesen ez a hasonlóság bármely méretü felületre ill. sugarú tárcsára igaz.

A véges számú koncentrált erő hatására keletkező feszültségeket is számíthatjuk összegzéssel. A számított (1) $\sigma_{\text {zi }}$ feszültségeket egyszerúen csak össze kell adni, mert minden i komponensű feszültség egyformán z tengely irányú.

A (2);(3) $\sigma_{\text {ri }}$ feszültségúek már eltérő irányúak, ezért az $F$ felület súlypontján és az x;y ponton keresztül felvett síkra kell vetíteni, hogy megkaphassuk a fö feszültségi irányokat.

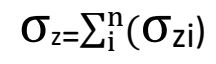

$\sigma_{\mathrm{r}}=\sum_{\mathrm{i}}^{\mathrm{n}}\left(\sigma_{\mathrm{ri}} * \cos ^{2} \sigma_{\mathrm{i}}+\sigma_{\alpha \mathrm{i}} * \sin ^{2} \alpha \mathrm{i}\right)$ és

$\sigma_{\alpha}=\sum_{\mathrm{i}}^{\mathrm{n}}\left(\mathbf{S}_{\alpha \mathrm{i}} * \cos ^{2} \alpha \mathrm{i}+\sigma_{\mathrm{ri}} * \sin ^{2} \alpha \mathrm{i}\right)$

\section{A SZÁMÍTÁSI MÓDSZER ALKALMAZÁSÁVAL MEGOLDOTT ANOMÁLIA}

Elöször bemutatok egy példát a rugalmas homogén és izotróp féltérre vonatkozóan.

Vegyünk egy $40 \mathrm{MPa}$ teherbírású talajt és terheljük egy $163 \mathrm{~mm}$ sugarú merev és egy hajlékony tárcsával, amelynek terhelése $50 \mathrm{kN}$. Ugyanezt a talajt terheljük meg egy iker kerékkel, amelynek terhelése szintén $50 \mathrm{kN}$, de két db egyenként $200 * 200 \mathrm{~mm}$-es méretü terhelő felülete van; a felületek egymástól mért távolsága $130 \mathrm{~mm}$.

Ezt a példát azért választottam, mert a jelenlegi pályaszerkezet méretezési utasítás [9] és a korábbiak is az MSZ 2509/4-1989 szerinti BB Benkelman tartóval az ikerkerek között mért behajlást ilyen méretü tárcsával modellezték a többrétegü méretezési módszer esetén.

A bemutatott módszer segítségével mindhárom terhelési típusra elvégeztem a számításokat hossz -és keresztirányban, ahol az irányt az ikerkerék jelöli ki (3. sz. ábra).

Külön feltüntettem az abroncs alatti behajlásokat vastag piros színnel. Jól látható, hogy az ikerkerekek között mért behajlás kisebb, mint a helyettesítő $163 \mathrm{~mm}$ sugarú hajlékony, ill. merev tárcsa alatti. Az is látszik, hogy az iker kerekek által okozott keresztirányú behajlás alapvetően eltér a hosszirányú behajlástól.

Természetesen felmerülhet, hogy milyen mérésekkel igazolható a számítás. 1990-ben az M1-es autópálya épülő szakaszán, a 80+480-80+675 kmsz. között, 41 geodéziailag bemért, rögzített mérési ponton az altalajtól az összes pályaszerkezeti réteg teherbírását mértük, tárcsás ill. BB tartóval az ikerkerekek között [10]. Ekkor tapasztaltuk, hogy a 0,4 MPa megoszló terhelésü (28,275 kN-nal terhelt) tárcsával nagyobb összenyomódást mértünk, mint az $50 \mathrm{kN}$ terhelésnél, az ikerkerekek között. 


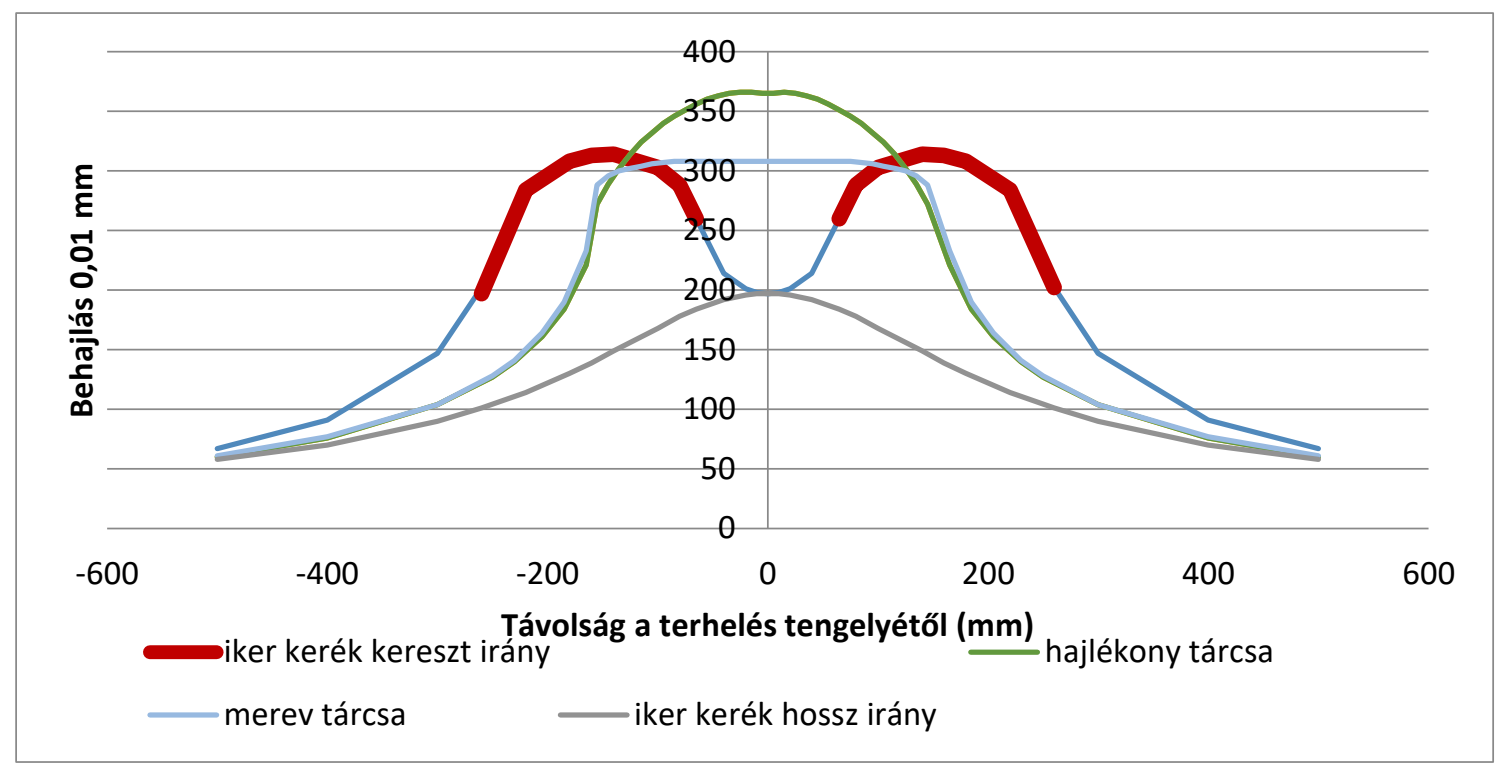

3. ábra: Behajlási teknő alakja különböző terhelő felületeknél homogén féltéren.

Az akkor tapasztalt „,anomáliára” ez a számítási módszer ad megfelelő magyarázatot, ami egyben tökéletesen igazolja a módszer helyességét. A hiteles mérési jegyzőkönyvek a mai napig megvannak, a mérést az akkori BUV labor végezte, precíz munkájukért utólag is köszönet, nélkülük a bemutatott módszer „csak” egy hipotézis lenne.

\section{Merev és hajlékony tárcsa avagy 2 vagy $\mathbf{p} / 2$}

Rugalmas homogén és izotróp féltér esetén, az egyenletesen terhelt $r$ sugarú tárcsa tengelyében mért teljes összenyomodás, szintén Boussinesqu szerint, mert ő integrálta először ezt a felületet a tengelyre:

$\mathrm{S}=\frac{2 * \mathrm{r} * \mathrm{p}}{\mathrm{E}} *\left(1-\mu^{2}\right)$ hajlékony tárcsa esetén a már ismertetett (12),

de $S=\frac{\pi * \mathrm{r} * \mathrm{p}}{2 * \mathrm{E}} *\left(1-\mu^{2}\right)$ merev tárcsa esetén.

Az eltérés abból adódik, hogy a merev tárcsa alatt kialakuló feszültség eloszlása:

$\sigma_{\mathrm{y}}=\frac{\mathrm{p} * \mathrm{r}}{2 * \sqrt{\mathrm{r}^{2}-\mathrm{y}^{2}}}=\frac{\mathrm{P}}{2 * \mathrm{r} * \pi \sqrt{\mathrm{r}^{2}-\mathrm{y}^{2}}}$

y a tárcsa tengelytől mért távolság

$\mathrm{r}$ a tárcsa sugara

$\mathrm{p}=\frac{P}{F}$, és $\mathrm{F}=\mathrm{r}^{2 *} \pi$

A tárcsa tengelyén kívül az összenyomódásra vonatkozóan nincs egyszerü megoldás, mivel az integrálás zárt alakban nem végezhető el.

A (16) feszültségeloszlásból látszik, hogy a tárcsa szélén a feszültség a végtelenhez konvergál. Végtelent a matematika tudja értelmezni, a fizika viszont nem.

Mi történik a tárcsa szélénél, ill. annak közelében? Nagyon leegyszerüsítve, talaj esetén talajtörés, kötőanyaggal rendelkező anyagok vagy szilárd anyagok esetén, az anyag plasztikus, elasztikus állapotba kerül, mert a feszültség az elmélet szerint a végtelenhez tart. Ezen a területen a Hooke- törvény már közelítően se lesz igaz.

A valós folyamat során, a feszültség egy véges állapot felé tart, amely után a deformáció a feszültség növekedése nélkül is folyamatosan nő.

Ez utóbbi tény azért fontos, mert a tárcsa szélénél nem szükséges olyan modellt felállítani, amely a végtelenhez közelít. Elégséges, ha a tárcsa szélénél felvett feszültség véges, de már „,folyást” okoz. 
Amikor az egyenletesen megoszló terhelést n számú koncentrált erővel helyettesítettük, akkor valójában n számú hasábot veszünk alapul, amelyen P/n koncentrált erő müködik.

Ez a hasábköteg azért modellezi jól a hajlékony tárcsát, mert egymás mellett feszültség átadása nélkül „," irányba el tud mozdulni, így képes a terhelés által okozott behajlási „teknő” alakját felvenni.

A merev tárcsát is ezzel az n számú hasábbal fogjuk modellezni, ezek nagysága $P_{\mathrm{i}}$ követi a (17) eloszlást, avval a megkötéssel, hogy a tárcsa végénél felvett erő nagyságának maximuma van (19).

$\mathrm{P}_{\mathrm{i}}=\mathrm{F} * \mathrm{n} * \frac{\mathrm{P}}{2 * \mathrm{r} * \pi \sqrt{\mathrm{r}^{2}-\mathrm{y}^{2}}}=\frac{\mathrm{r} * \mathrm{P}}{2 * \mathrm{n} * \sqrt{\mathrm{r}^{2}-\mathrm{y}^{2}}}$,

$\mathrm{n}$ az a darabszám, ahány egyenlő részre osztottuk az $\mathrm{F}$ felületet.

$\mathrm{P}_{\max }=\mathrm{F} * \mathrm{n} * \frac{\mathrm{P}}{2 * \mathrm{r} * \pi \sqrt{\left(\frac{\mathrm{x}}{2}\right)^{2}}}=\frac{\mathrm{r} * \mathrm{P}}{2 * \mathrm{n} * \sqrt{\left(\frac{\mathrm{x}}{2}\right)^{2}}}$, ahol $\mathrm{x}=\sqrt{\frac{\mathrm{F}}{\mathrm{n}}}$

Az így felvett terheléssel modelleztük a merev tárcsát (3. sz. ábra). A modell annál jobb, minél jobban közelíti a merev tárcsa alatti azonos behajlást. Tökéletes megoldás nem létezik, mivel a tárcsa szélénél az anyagnak meg kell folynia, amely sérti a Hooke-törvényt, amivel számolunk.

Az eltérés azonban olyan kicsi (század ill. ezred mm-es nagyságrendü), hogy nincs gyakorlati jelentősége, azt azonban hangsúlyozni kell, hogy ezeken a helyeken az anyag nagyon jelentős maradó alakváltozást szenved.

A leírt módszerrel bármilyen feszültségeloszlás bármilyen felületre modellezhető, és - ami a legfontosabb - az okozott deformációk viszonylag pontosan számíthatók.

Nagyon fontos, hogy a 2 vagy $\mathrm{p} / 2$ az integrálás eredménye, homogén és izotróp rugalmas féltérben a tárcsa tengelyére igaz, de ez nem általános érvényủ szabály és nem vonatkozik rétegzett talajokra, legfőképpen nem az útpályaszerkezetre.

Egy kicsit elöre lépve, megadok egy félig merev pályaszerkezetet és a modell által számított behajlásokat.

Az altalaj teherbírása $40 \mathrm{MPa}$, a Ckt-4 $150 \mathrm{~mm}$ vastag, $\mathrm{E}_{\mathrm{din}} \sim 5000 \mathrm{MPa}$, amelyen $150 \mathrm{~mm}$ vastag aszfalt pályaszerkezet található, aminek az alakváltozási modulusa dinamikusan mérve $14{ }^{\circ} \mathrm{C}$-on $\mathrm{E}_{\mathrm{din}} \sim 3300 \mathrm{MPa}$.

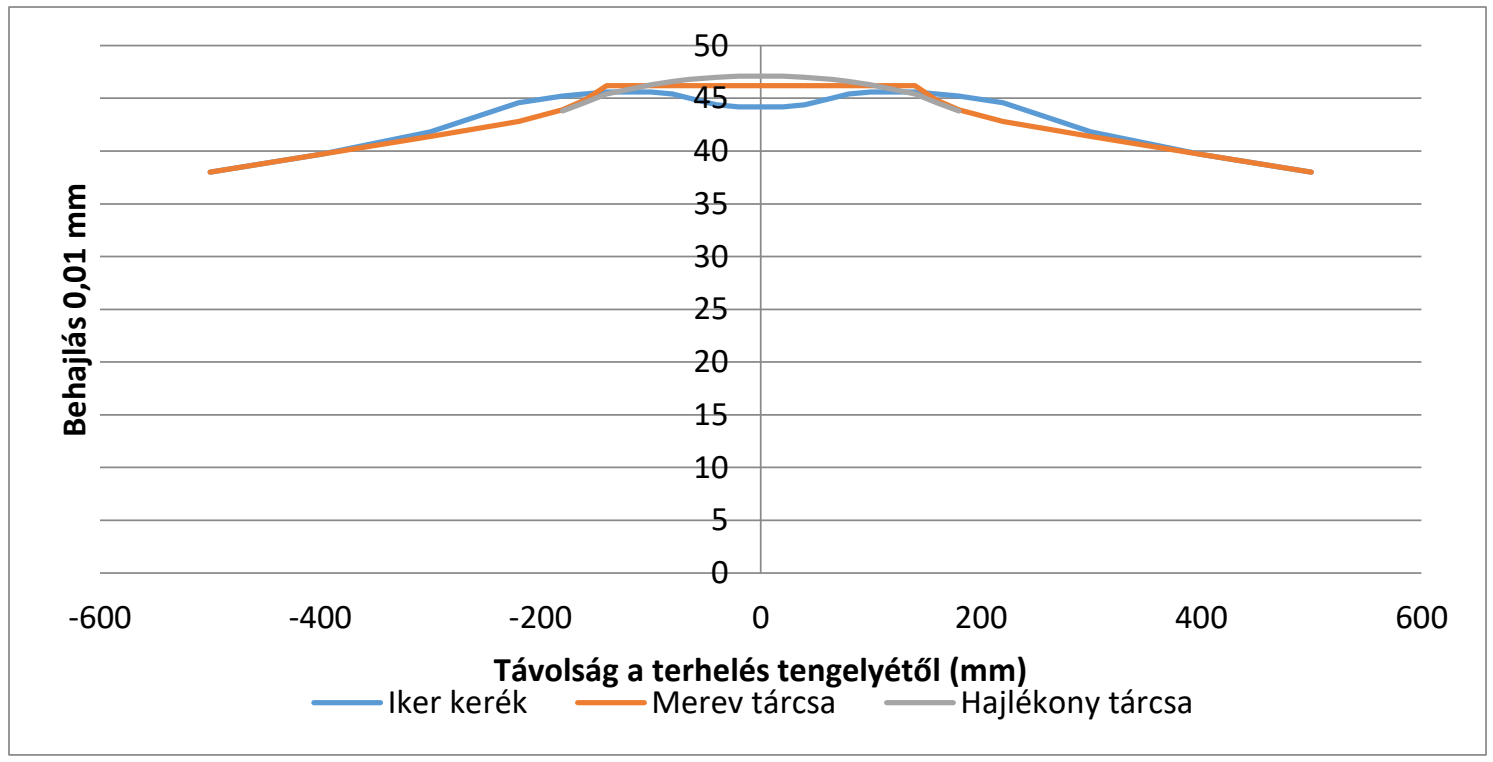

4. ábra: Útpályaszerkezeten kialakuló behajlási teknő különböző tereheléseknél.

A számított behajlásokat 0,01 mm-ekben fejeztük ki. Látható, hogy a különböző mérési módszerek, ikerkerék között Benkelman tartóval vagy ezt közelítő 163 mm-es akár hajlékony akár merev tárcsával közel hasonlók, de nem adnak azonos eredményt. 
Az is szembetünő, hogy a merev és a hajlékony tárcsa is szinte ugyanazt a behajlási teknőt hozza létre.

Mérnöki tapasztalatunk szerint is, minél merevebb és vastagabb pályaszerkezeten mérünk teherbírást, annál kisebb a jelentősége annak, hogy merev vagy hajlékony a terhelő tárcsa.

Ezt a tapasztalatunkat most már számszerüsíteni is tudjuk.

Az ikerkerék alatti terhelés $163 \mathrm{~mm}$ sugarú tárcsával modellezhető, az elkövetett hiba a pályaszerkezet merevségének függvényében változó (4. ábra). A pályaszerkezetben ébredő tényleges feszültségek számítására az ilyen modell nem alkalmas, de erre soha nem is használták.

\section{TÖBBRÉTEGŰ ÚTPÁLYASZERKEZET}

Többrétegü rendszernél az Odemark-Ivanov (1949) által javasolt $h_{\mathrm{i}}=\mathrm{h}_{\mathrm{i}} * \sqrt[3]{\frac{E i}{E a}}$ közismert összefüggést javaslom, ahol a $h_{i}$ az $i$. réteg vastagsága, $E_{i}$ réteg alakváltozási modulusa, $E_{a}$ az altalaj alakváltozási modulusa, $\mathrm{hh}_{\mathrm{i}}$ az $\mathrm{i}$. réteg helyettesítő rétegvastagsága.

Több réteg esetén is mindig a legalsó réteghez, az altalajhoz viszonyítunk.

Az összenyomódásokat is réteghatáronként számoljuk, de az adott réteg alakváltozási modulusával osztunk. Ez a módszer bármely x;y pontra vonatkozóan alkalmazható.

Másik eljárás, amit hazánkban is alkalmazunk, az un. egyenérték alakváltozási modulus, ami azt jelenti, hogy a mért behajlásból - valamilyen módszerrel mért és BB-re átszámított - kiszámítjuk azt az egyenérték alakváltozási modulust, amely ugyanazt a behajlást eredményezné.

Természetesen ezt számszakilag megtehetjük, hiszen ha adott a „valamilyen” módon mért behajlás értéke, akkor az át tudjuk számítani pl. egy $163 \mathrm{~mm}$ átmérójü hajlékony tárcsán mért $50 \mathrm{kN}$ terhelés esetére, amiből kapunk egy „egyenérték” alakváltozási modulust.

A méretezésnél ebből az egyenérték alakváltozási modulusból indulunk ki, amely rétegre, ha $\mathrm{x}$ vastagságú E alakváltozási modulusú réteget teszünk, akkor ki tudjuk számítani az új réteg behajlását, mint kétrétegü rendszerét.

Ez a mai tervezési eljárás, a módszernek nagyon nagy előnye, hogy nagyon egyszerü.

Hátránya, hogy az alkalmazott „egyenérték” alakváltozási modulus a hajlékony tárcsa tengelyén kívül sehol se ad elfogadható eredményt, vagyis csak és kizárólag a terhelés tengelyére vonatkozóan kapunk a mérésnek is megfelelö behajlást.

Az „egyenérték” alakváltozási modulusú féltérben tetszőlegesen felvett x;y pontban már megközelítően se számíthatunk a rétegzett útpályaszerkezeten mért behajlást, ezért a rétegzett útpályaszerkezet nem helyettesíthető egyenérték alakváltozási modulusú féltérrel.

További hátrány, hogy minden mérést át kell számítani a BB Benkelmann tartóval mért értékre.

Az átszámítási „kényszernek” nemcsak ez az oka, a másik igen nyomós ok, hogy a méretezéshez használt élettartam görbék is a BB mérésen alapulnak.

\section{KÜLÖNBÖZŐ MÓDSZERREL MÉRT BEHAJLÁSOK ÁTSZÁMÍTÁSÁNAK LEHETŐSÉGE ÉS KORLÁTAI}

A törekvés az, hogy az $\mathrm{X}$ módszerrel mért behajlást számítsuk át, $\mathrm{f}(\mathrm{x})$ függvény segítségével másik Y módszerrel mért behajlássá.

Ha létezne valóságos „egyenérték” féltér, amely a rétegzettet helyettesíti, akkor létezne ilyen $\mathrm{f}(\mathrm{x})$ függvény is, de ilyen nincs, ezért az $\mathrm{f}(\mathrm{x})$ függvény keresése is a sok hiábavaló dolog közé sorolandó.

Amit állítok, hogy nem létezik, és nem létezhet olyan módszer, amelyik a mért pályaszerkezet rétegzettsége, felépítése nélkül az $\mathrm{X}$ módszerrel mért behajlást elfogadható pontossággal át tudná számítani Y módszerrel mért behajlássá. Természetesen, hogy ki mit ért elfogadható pontosságon, azon lehet vitatkozni.

A felsorolandó problémák közismertek, de mindegyik összefügg a pályaszerkezet rétegzettségével.

1. Dinamikus hatás

- A mért és a számított alakváltozás, vagy behajlás függ az alakváltozási modulustól, ami pedig függ a terhelés sebességétől. Ez a függés nem azonos a hidraulikus kötésű 
pályaszerkezet, a bitumenes kötőanyagú rétegek és a kötőanyag nélküli rétegek esetén. Előfordulhat, hogy míg X módszerrel mérve a kétféle pályaszerkezetet azonos mérési eredményre jutunk, de Y módszerrel már teljesen eltérő mérési eredményt kapunk.

- Másik nem elhanyagolható ok, hogy a kötött, de telített talajok nagy terhelési sebességnél -pl. KUAB mérés- „mereven” viselkednek, adott esetben összenyomhatatlanok a terhelés ideje alatt, míg ez a talaj statikus tárcsás mérés vagy BB mérés esetén, jelentős alakváltozást szenved.

- Szemcsés talajoknál közismert a vibráció hatása, ami szintén nem hanyagolható el.

\section{Mérési módszer, a mérés körülményei}

- Nem mindegy, hogy a behajlás mérésekor a rugalmas visszaalakulást vagy a maradó alakváltozást is tartalmazó behajlást mérjük. Pl. a BB a rugalmas visszaalakulást mér, míg tárcsás mérés, KUAB stb. a teljes alakváltozást.

- A mérések többségénél eltérő módon és mértékben, de a mért pontot, pontokat nemcsak a méréskor figyelembe vett $\mathrm{P}$ erő terheli, hanem $\mathrm{Pi}$ is, amely távolabb van a mérés helyétôl. Pontosabban a tárcsás mérésnél a terhelő jármü, mint ellenteher x m-es távolságból ráterhel a méröpontra, a mérőkar talpaira; ez a terhelés a terhelés közben csökkeni fog, majd tehermentesítéskor ismét ráterhel.

Ezeket a hatásokat elhanyagoltuk, mert nem tudtuk kiszámolni.

Ugyanilyen hatás észlelhető a BB méréskor, amikor a terhelési ponttól, 1,92 m távolságban lévő, szintén $50 \mathrm{kN}$ terhelésủ kerék is terheli a mérési pontot, valamint a BB tartó talpait. Továbbá a mért kerék is ráterhel a BB tartó lábaira, ami 1,5 és 2,5 m-es távolságban vannak, vagyis a mérést kiterjedt behajlási teknőben végezzük.

A KUAB-nál ilyen hatásokkal nem kell számolni, de a Lacroix-típusú, gördülőkerekes mérőberendezéseknél már igen.

- Azt gondolnánk, hogy a mérőeszközök egyszerüen statikus és dinamikus terhelési csoportba sorolhatók, pedig ez nem igaz. Minden mérés „dinamikus”, csak a terhelés sebessége eltérő, ténylegesen statikus terhelésnek egy épület tekinthető.

Néhány mérési módszer, közelítő, nem egzakt terhelési sebessége, $\mathrm{mm} /$ perc dimenzióban (1. sz. táblázat).

1. táblázat: Terhelés típusa és a becsült terhelési sebesség.

\begin{tabular}{|l|l|}
\hline \multicolumn{1}{|c|}{ Terhelés típusa } & \multicolumn{1}{c|}{$\begin{array}{c}\text { Terhelés sebessége } \\
\text { mm/perc }\end{array}$} \\
\hline Könnyü ejtősúlyos & 7800 \\
\hline KUAB & 3200 \\
\hline Laboratórium & 725 \\
\hline Lacroix & 28 \\
\hline Tárcsás & 0,3 \\
\hline
\end{tabular}

Aszfaltkeverékek esetén adott hőmérséklet mellett az alakváltozási mudulus „Easzf”és a terhelés sebességének összefüggése „ $\mathrm{E}_{\text {aszf }}=\mathrm{a} * \ln (\mathrm{v})+\mathrm{b}$ ” alakú, ahol „V” a terhelés sebessége.

Az MSZ EN 12697-26 „Meleg aszfaltkeverékek vizsgálati módszere” E5. fejezete szabvány lehetővé teszi a mestergörgék meghatározását. A MEPDG-féle útpályaszerkezet méretezéséhez ajánlanak hasonló módszert a megfelelő alakváltozási modulus meghatározásához [11] [12]. 


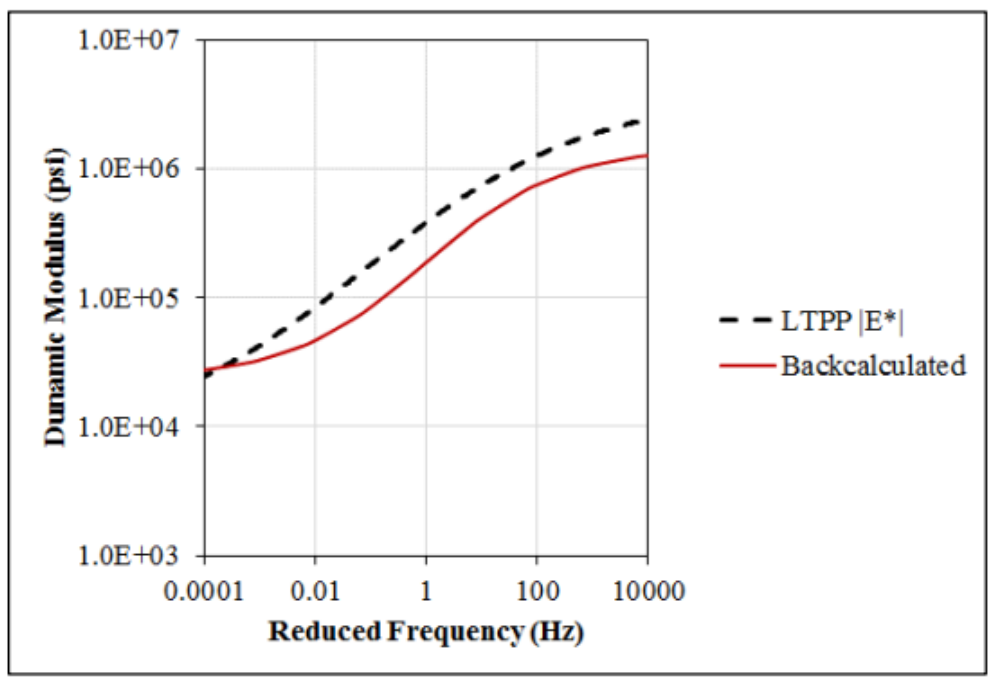

Source: FHWA.

5. ábra: Dinamikus modulus különböző tehelési ferekvencián.

3. Mérést befolyásoló külső körülmények

Ezek a hatások leginkább az időjárási viszonyok, az altalaj víztartalmára vonatkozó viszonyok.

Jelentőségük az eltérő mérések átszámíthatóságának tekintetében ott van, hogy befolyásolják a méréskori alakváltozási modulust. Az átszámíthatóságot nehezíti az esetleg eltérő terhelő erő és felület, de ezek szerencsére közel azonosak.

\section{A BEMUTATOTT MÓDSZER ALKALMAZÁSI LEHETŐSÉGE}

A számítási módszerrel, ha ismert a behajlási teknő, akkor ki lehet számolni az altalaj méréskori teherbírását és a pályaszerkezeti rétegek alakváltozási modulusát.

Az így kapott alakváltozási modulusok a mérési módszerre jellemzőek, értékük függ a terhelési sebességtöl.

A módszert egy példán keresztül mutatjuk be. A mért szakasz hossza 3,5 km.

2016. év novemberében egy útszakaszon mértek KUAB-bal $14{ }^{\circ} \mathrm{C}$-os hőmérsékleten, majd egy Lacroix jellegü gördülőkerekes módszerrel 2020. év júliusában $22{ }^{\circ} \mathrm{C}$-os hőmérsékleten.

Pályaszerkezet:

\begin{tabular}{lr}
$5 \mathrm{~cm} \mathrm{AB}-12$ & 1977 \\
$4 \mathrm{~cm} \mathrm{AB}-12$ & 1970 \\
$6 \mathrm{~cm} \mathrm{U-20}$ & 1970 \\
$15 \mathrm{~cm}$ soványbeton & 1970 \\
\multicolumn{1}{c}{ közepesen kötött talaj }
\end{tabular}

A soványbeton, valószínűen B60, amely a mai Ckt-4 hez áll a legközelebb, de pontosan nem ismerjük, mint ahogy azt sem tudjuk, hogy a soványbeton alatt milyen vastagságú homokos kavics található, amit most figyelmen kívül hagytunk. 


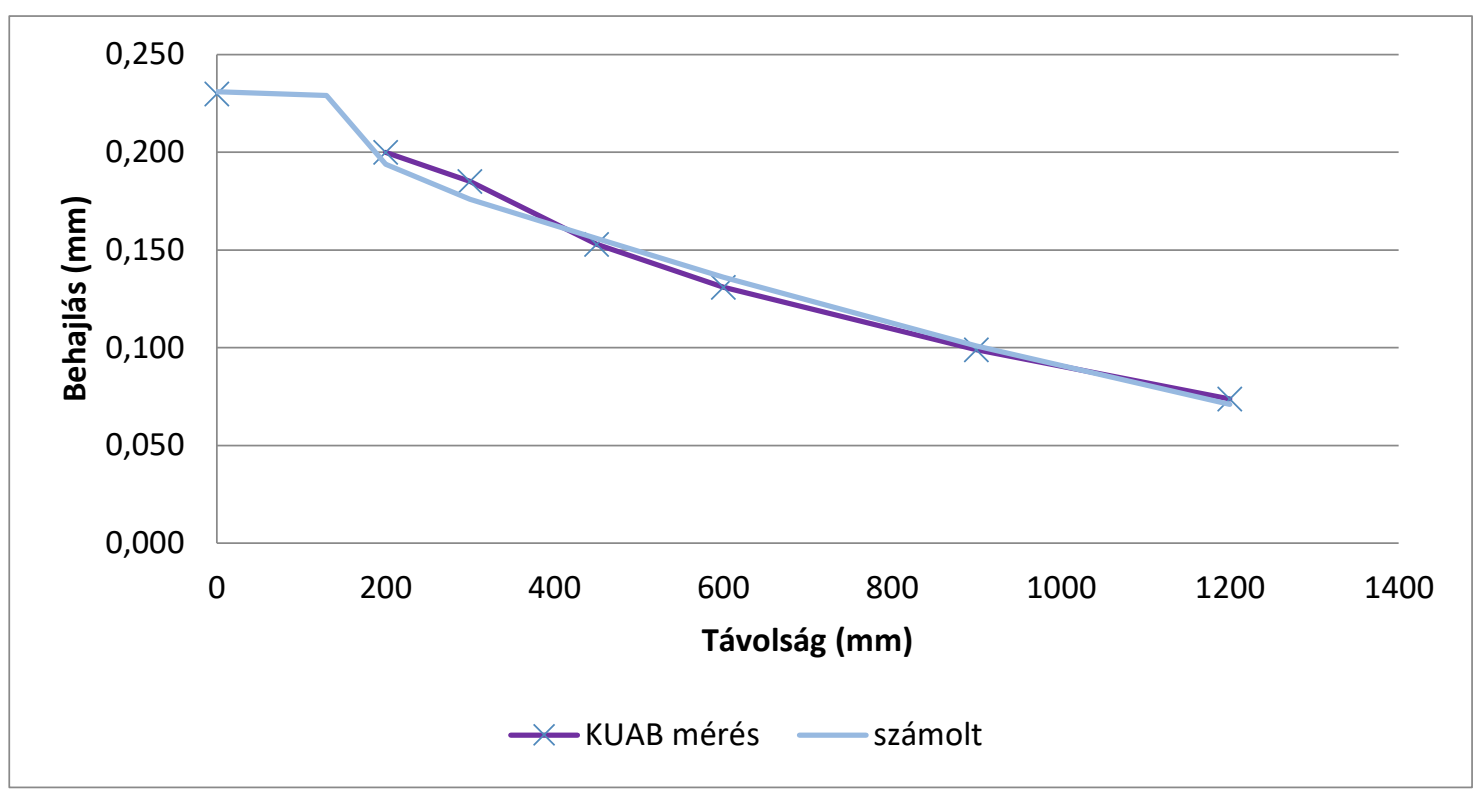

6. ábra: KUAB teherbírás mérés által keltett és számított behajlási teknő.

A KUAB mérésből számított eredmények:
$15 \mathrm{~cm}$ aszfalt $14{ }^{\circ} \mathrm{C}$ hömérsékleten
$4100 \mathrm{MPa}$,
$15 \mathrm{~cm}$ soványbeton
$4000 \mathrm{MPa}$,
közepesen kötött talaj
$110 \mathrm{MPa}$.

A KUAB mérések alapján az ismertetett számítási módszerrel merev terhelő tárcsára meghatároztam a pályaszerkezeti rétegek alakváltozási modulusát, és a behajlási teknőt (6.sz ábra). A mért és a számított behajlási teknő jól egyezik.

A Lacroix-típusú gördülő kerekes mérésre vonatkozóan iker kerekes terhelést és rugalmas behajlást alapul véve számítottam a pályaszerkezeti rétegek alakváltozási modulusát, és a behajlási teknőt, ami szintén jól egyezik a méréssel. A 7. sz. ábrán feltüntettem a KUAB mérés eredményét, hogy a két mérési módból adódó eltérés jól látható legyen. Az eltérésnek három fő oka, az eltérő hőmérséklet, eltérő terhelési sebesség és eltérő az altalaj méréskori állapota.

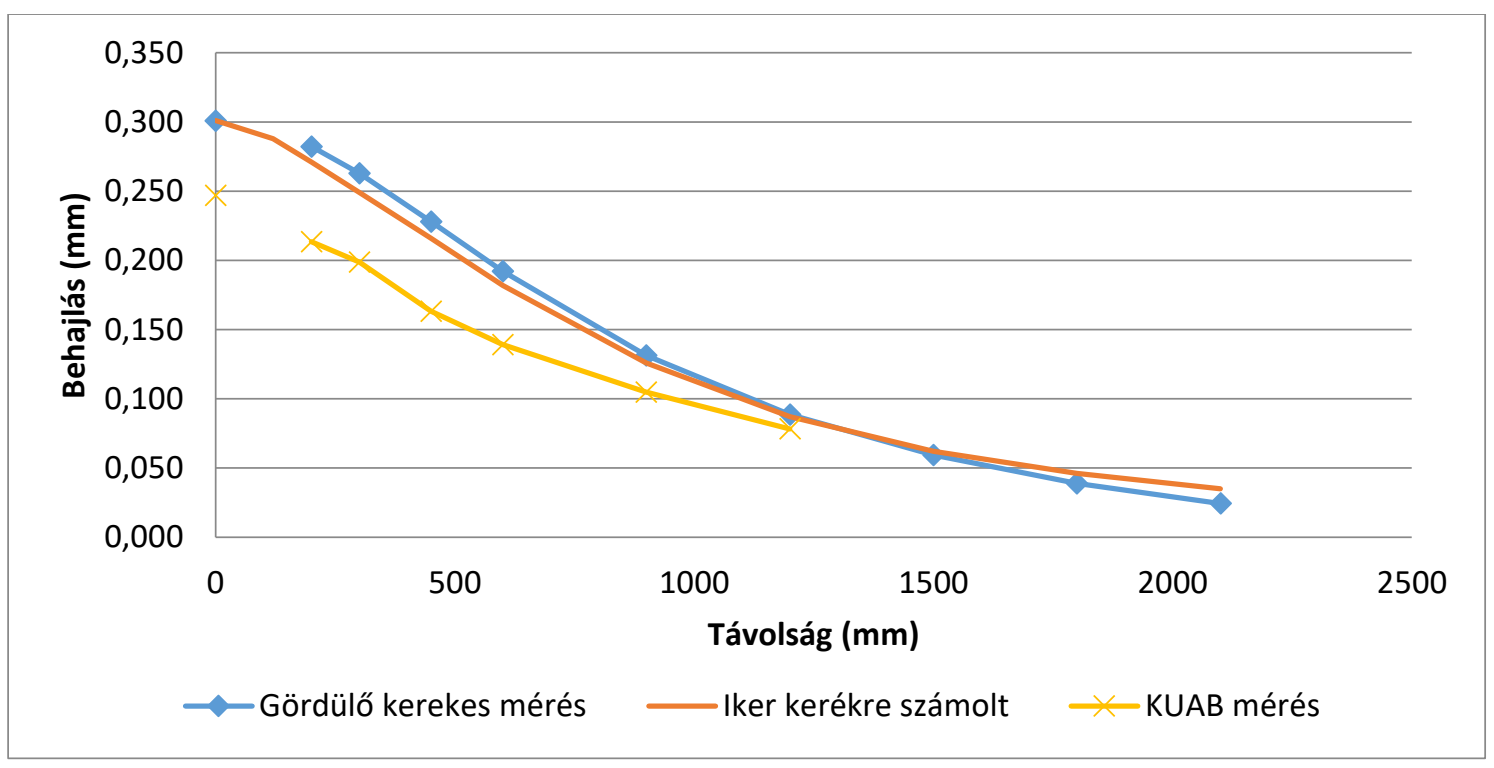


7. ábra: Gördülőkerekes teherbírás mérés által keltett és számított behajlási teknő.

A Lacroix-típusú mérésből számított eredmények:

$15 \mathrm{~cm}$ aszfalt $22^{\circ} \mathrm{C}$ hömérsékleten

$2000 \mathrm{MPa}$,

$15 \mathrm{~cm}$ sovány beton

$3500 \mathrm{MPa}$

közepesen kötött talaj

$90 \mathrm{MPa}$.

Az altalajra vonatkozó alakváltozási modulusok a gördülö kerekes mérésnél inkább statikusnak, a KUAB mérésből származó pedig dinamikus alakváltozási modulusnak tekintendő. Az altalajra vonatkozó alakváltozási modulust viszonylag pontosan meg lehet határozni, mivel a 900; 1200; 1500; 1800; 2100 mérőpontok mind az altalaj teherbírását jellemzik. A pályaszerkezeti rétegekre vonatkozóan azonban kevés a mérőpont, így sokkal nagyobb a bizonytalanság is. A bizonytalanság azon pályaszerkezeti rétegek esetén növekszik, amikor a várható alakváltozási modulus közel hasonló. Bár alapvetően különböznek egymástól a hidraulikus kötőanyagú rétegek az aszfalt rétegektől, de van olyan hőmérséklet tartomány, amikor az alakváltozási modulus hasonló, pl. $10-15{ }^{\circ} \mathrm{C}$ hőmérsékleten.

A javasolt módszert, ami kizárólag egzakt elméleti megfontolásokon alapszik, összehasonlítottuk a 2. sz. táblázatban a KUAB és egyéb dinamikus mérésekhez javasolt eljárással [13].

Itt a szerzők négy alapesetet elemeznek mindegyik esetben háromféle pályaszerkezettel, ahol megadták a szerkezeti rétegek vastagságát és a rugalmassági modulusokat is, valamint 0,$305 ; 610$; és a $914 \mathrm{~mm}$ távolságban a behajlásokat.

2. táblázat: Számítási módszer összevetése más elfogadott módszerrel.

\begin{tabular}{|l|l|l|l|l|l|l|l|l|}
\hline $\mathrm{mm}$ & & $\mathrm{psi}$ & $\mathrm{MPa}$ & láb & $\mathrm{mm}$ & hüvelyk & $\mathrm{mm}$ & $\begin{array}{l}\text { Saját } \\
\text { számított }\end{array}$ \\
\hline 50 & Aszfalt & 500000 & 3450 & 0 & 0 & 0,048 & $\mathbf{1 , 2 1 9 2}$ & $\mathbf{1 , 2 4 9}$ \\
\hline 150 & Base & 25000 & 172,5 & 1 & 305 & 0,026 & $\mathbf{0 , 6 6 0 4}$ & $\mathbf{0 , 7 5 6}$ \\
\hline & talaj & 7500 & 51,75 & 2 & 610 & 0,014 & $\mathbf{0 , 3 5 5 6}$ & $\mathbf{0 , 3 8}$ \\
\hline & & & & 3 & 914 & 0,009 & $\mathbf{0 , 2 2 8 6}$ & $\mathbf{0 , 2 1 9}$ \\
\hline & & & & & & & & \\
\hline 125 & Aszfalt & 500000 & 3450 & 0 & 0 & 0,027 & $\mathbf{0 , 6 8 5 8}$ & $\mathbf{0 , 6 8 3}$ \\
\hline 200 & Base & 25000 & 172,5 & 1 & 305 & 0,02 & $\mathbf{0 , 5 0 8}$ & $\mathbf{0 , 5 1 8}$ \\
\hline & talaj & 7500 & 51,75 & 2 & 610 & 0,014 & $\mathbf{0 , 3 5 5 6}$ & $\mathbf{0 , 3 5 3}$ \\
\hline & & & & 3 & 914 & 0,01 & $\mathbf{0 , 2 5 4}$ & $\mathbf{0 , 2 2 5}$ \\
\hline & & & & & & & & \\
\hline & & & & 0 & 0 & 0,018 & $\mathbf{0 , 4 5 7 2}$ & $\mathbf{0 , 4 4 4}$ \\
\hline 230 & Aszfalt & 500000 & 3450 & 1 & 305 & 0,015 & $\mathbf{0 , 3 8 1}$ & $\mathbf{0 , 3 8 1}$ \\
\hline 150 & Base & 25000 & 172,5 & 2 & 610 & 0,012 & $\mathbf{0 , 3 0 4 8}$ & $\mathbf{0 , 3 0 2}$ \\
\hline & talaj & 7500 & 51,75 & 3 & 914 & 0,009 & $\mathbf{0 , 2 2 8 6}$ & $\mathbf{0 , 2 2 6}$ \\
\hline
\end{tabular}

$\mathrm{psi}=$ font/négyzethüvelyk (pound/inch $\left.{ }^{2}\right)$

Saját módszerünkkel is kiszámoltam a várható behajlásokat mindegyik esetre, amiből most csak az I. esetet közlöm a 2. táblázatban. Az eltérés minden esetben minimális, ami szintén erősíti a leírt számítási módszer helyességét. Itt jegyzem meg, hogy szinte minden módszer felvesz egy különböző eljárásokkal számított „összenyomhatatlan” réteget, mert e nélkül a számított behajlási teknő és a valóságos mérés elfogadhatatlan mértékben eltér egymástól.

Nekünk a számításhoz nincs szükségünk ilyen elméletileg is nehezen indokolható rétegre. 


\section{HATÁRMÉlYSÉG AVAGY ÖSSZENYOMHATATLAN RÉTEGEK}

Jól ismert tudományos vélekedés, hogy az R sugarú tárcsának a hatásmélysége (2-3)*R mélység körül van.

Vizsgáljuk azonban meg, hogy ez elméletileg lehetséges-e. Az tény, hogy ilyen mélységben a $\sigma_{z}(1)$ már töredéke a tárcsa alatti terhelésnek, de nem nulla, a mélység függvényében $1 / Z$ alakban csökken.

Természetesen nem is a feszültség létét vagy nem létét vitatják, hanem a kialakuló süllyedést. $\mathrm{Az}$ állítás mögött az húzódik meg, hogy pl. $\mathrm{Z}_{\mathrm{h}}=6^{*} \mathrm{r}$ határ mélységben a terhelő tárcsa alatt nincs mérhető összenyomódás, amelynek oka nincs megmagyarázva.

$\mathrm{Az}$ állítással az az igazi probléma, hogy a $Z_{\mathrm{h}}$ mélységben a terhelő tárcsa tengelyében lévő elemi anyagnak nincs információja a terhelö tárcsa méretéről, ezért nem is „tudhatja”, hogy „neki” most éppen össze kell-e nyomódnia vagy sem.

A $Z_{\mathrm{h}}$ mélységben lévő elemi anyagnak csak a feszültség komponensekröl és feszültség terjedésének sebességéröl van információja, amely feszültség hullám formában terjed.

Az viszont előfordulhat, főleg a nagyon kicsi vízáteresztő képességü telített kötött talajoknál, hogy az igen rövid idejü dinamikus terhelésnél a telített talaj összenyomhatatlan, hiszen a víz nem tud a terhelés ideje alatt kiszorulni a terhelési zónából, vagyis nem jöhet létre térfogat változás és ennek következében z tengely irányú összenyomódás sem.

Kvázi statikus terheléskor, tárcsás mérés vagy a $\mathrm{BB}$ mérés közben a terhelési idő lényegesen több, így az összenyomhatatlan réteg kialakulása már nem valószínű.

Dinamikus teherbírás mérés mellett valószínüleg a gördülökerekes teherbírás mérésekor is kialakulhat összenyomhatatlan réteg a talajvíz szintjével egyezően, föleg a IV-IX talajfajták esetén, ezért a méréskori talajvízszint és a pályaszint közötti különbség ismerete fontos lenne.

\section{ANYAG ÁLLANDÓK}

A lineárisan rugalmas homogén és izotróp anyagra vonatkozik a Hooke-törvény.

Az anyag állandók a „E” rugalmassági modulus MPa, és a $\mu$ Poisson-féle harántkontrakciós tényező, amely egynél kisebb dimenziótlan szám. Nagyon fontos, hogy az „E” modulust közvetlenül soha nem mérjük, hanem csak számítjuk.

Az útpályaszerkezeti rétegek, mint jól tudjuk, nem tisztán rugalmas anyagok. A terhelés és az azt követő tehermentesítés során az anyag maradó és rugalmas alakváltozást szenved. A két alakváltozás együttes értékéből és a terhelő legnagyobb feszültségből kapjuk meg az alakváltozási modulust. A rugalmas viselkedést jellemző rugalmassági modulus számításánál a tehermentesítés utáni rugalmas visszaalakulást szabad figyelembe venni.

A leírt süllyedés képletek az anyag adott állapotában, hömérséklet, víztartalom, terhelés sebessége, feltételezik az „E” modulus állandóságát, adott feszültségtől való függetlenségét. Az „E” azonban nem független a feszültségtől, ezért nem állandó, pl. a teherbírásmérés ideje alatt sem. Elméletileg megoldható, hogy a számítások során a feszültséggel változó „E” értéket adjunk meg, de ez csak elméleti felvetés, mert az „E” értékének laboratóriumban is mérhető változása nem ismert a nagyon eltérő aszfaltkeverékek miatt. Így elméletileg lehetséges, de gyakorlatilag nem kivitelezhető.

A helyszíni teherbírásmérések többsége a teljes alakváltozást méri. A BB viszont rugalmas visszaalakulást mér, ami a jelenlegi méretezési módszer alapja és minden más egyéb mérési módot erre a mérési típusra számítunk át. Még a tárcsás mérés során is teljes alakváltozást mérünk, és ebből számoljuk az altalaj $E_{2}$ alakváltozási modulusát, bár a rugalmas visszaalakulás is mérhető és számítható lenne.

A KUAB mérés, a FWD a ejtősúlyos mérés, a gördülő kerekes mérések során meghatározott „E” értéke is a teljes alakváltozást tartalmazza.

A laboratóriumi vizsgálatok eredményként általában a teljes alakváltozásból számítják az E értékét, ha mégis eltérnek ettől, akkor a rugalmassági modulus csak egy tartományra vonatkozik, és nem tekinthető a teljes rugalmas visszaalakulásra jellemző értéknek. 
A BME Építőanyagok Tanszékén dr. Zsigovits Istvánnal több száz új és kifúrt aszfaltmintán végeztünk vizsgálatokat, amelyből egyértelmüen kiderült, hogy az $\mathrm{E}$ értéke függ a terhelés sebességétől és a minta nyomószilárdságától, ugyanazon terhelési nyomófeszültség mellett. Az aszfalt nyomószilárdsága pedig függ a vizsgálati hőmérséklettől is.

A nyomószilárdság ezen kívül még függ a teherismétlések számától is. A Főpolgármesteri Hivatal megrendelésére 1997-ben a probléma feltárására kutatást végeztünk, amely a fenti állításokat igazolja [13]. A tanulmány egyik fontos megállapítása, hogy a maradó alakváltozás a nyomószilárdság $70 \%$-át meghaladó terhelés esetén exponenciálisan növekszik.

A rugalmas alakváltozás is nő, de a változás lényegesen kisebb mértékű. Helyszíni teherbírásméréskor a BB méréstől eltekintve a teljes alakváltozást mérjük, a behajlási „teknő” is a teljes alakváltozásra jellemző. Az aszfalt pályaszerkezet teljes behajlásban játszott szerepe 2-5\%-nyi, ami tartalmazza a maradó alakváltozást is, elég csekély, de a számítási modellben használt helyettesítő rétegvastagság az Ei/Ea függvénye ezért nem elhanyagolható. Továbbá nem mindegy, hogy az E modulusnál a rugalmas vagy a maradó alakváltozást vesszük figyelembe, melyikkel számolunk.

Az aszfalt tönkremeneteli folyamata során az alakváltozási modulus folyamatosan csökken, ahol a maradó alakváltozás növekedése a döntő.

Egy nagyforgalmú foút pályaszerkezetén végzett teherbírásmérés legnagyobb behajlásából az aszfaltréteg tényleges összenyomódása néhány $0,01 \mathrm{~mm}$, ha ebböl fele származik a maradó alakváltozásból, akkor ez az aszfaltréteg gyakorlatilag tönkrement, jelentős lesz a várható deformáció, és tele lesz a burkolat mikro- és látható repedésekkel. Ehhez képest a rugalmassági modulus csökkenése lényegesen kisebb lesz. Ha ebből a pályaszerkezetből fúrt mintát veszünk, és rétegenként nyomószilárdság vizsgálatnak vetjük alá, akkor azt kapjuk, hogy rétegenként eltérő lesz a nyomószilárdság, az alakváltozási modulus és a rugalmassági modulus, amely mérésből rétegenként meg tudjuk állapítani az adott réteg állapotát várható élettartamát. A vizsgálatokból egyértelmüen kiderült, hogy a maradó alakváltozás döntő fontosságú adott pályaszerkezeti réteg állapotának megítélése szempontjából, de ez önmagában még nem indokolja az alakváltozási modulus figyelembevételét a rugalmassági modulus helyett.

A Boussinesq-féle feszültségkomponenseknél nem szerepel rugalmassági modulus és alakváltozási modulus, de szerepel a harántkontrakciós tényező, azaz a Poisson-féle szám, amely szintén nem állandó. Szerencsére a 0,2 és 0,5 közötti értékeknél a számított behajlás alig változik, így nagy hibát nem követünk el, ha a Poisson-számot állandónak tekintjük adott anyagra vonatkozóan.

Ha feltételezzük, a használt elméleti képletekből az derül ki, hogy a feszültségeloszlást az anyag „E” alakváltozási modulusa nem befolyásolja, akkor az „E”-nek, „csak” a közelítő eljárásként alkalmazott $\mathrm{h}_{\mathrm{i}}=\mathrm{h}_{\mathrm{i}} * \sqrt[3]{\frac{E i}{E a}}$ közismert helyettesítő rétegvastagságra van hatása.

Kérdés, hogy az alakváltozási vagy a rugalmassági modulussal számoljunk. Erre az egyszerü kérdésre azért nehéz egzakt választ adni, mivel a helyettesítő rétegvastagság se egzakt elmélet, hanem csak közelítés.

A helyettesítő rétegvastagság két eltérő „E” modulusú réteg azonos hajlítási merevségéből indul ki. Ez azt is jelenti, hogy hajlítás során a $h h_{i} / h_{i}$ magassági arányú rétegek ugyanakkora görbületi sugárral hajlanak, a szélső szálban keletkezett állandó húzófeszültség mellett.

A merevebb réteg esetén a tárcsás terhelés során kisebb behajlásokat, nagyobb görbületi sugarat kapnánk azonos terhelés mellett, mint a kevésbé merev réteg esetén. Ezért a merevebb réteget „bele” kell hajlítani a kevésbé merev rétegen keletkező görbületbe. Az egyensúly akkor áll be, amikor a hajlítási belső munka és a külső munka csökkenése egyenlővé nem válik. A külső munka azért csökken, mert a kevésbé merev rétegen mért elmozduláshoz képest a külső teher kisebb elmozdulást végez az összetett kétrétegü rendszeren.

A helyettesítő rétegvastagság alkalmazása esetén hallgatólagosan feltételezzük, hogy ez az egyensúly $\mathrm{hh}_{\mathrm{i}} / \mathrm{h}_{\mathrm{i}}$ következik be. 
Belátható, hogy a hajlítás, adott görbület felvételéhez, az alakváltozási modulus figyelembevétele esetén kisebb belső munkával jutunk el, mint az alakváltozási modulusnál nagyobb rugalmassági modulus figyelembevételével, ezért az alakváltozási modulussal kell számolni.

Ennek megfelelően a teherbírás mérésekor is a teljes (maradó és rugalmas) behajlás, együttes mérése a helyes, és evvel kell számolni.

A behajlási teknőből és a rétegvastagságokból viszonylag pontosan kiszámíthatjuk az alakváltozási modulusokat, de továbbra sem lesz információnk a pályaszerkezeti rétegre vonatkozó rugalmas és maradó alakváltozás mértékéről. Nem fogjuk tudni, hogy az alakváltozási modulus értéke azért annyi, mert a fáradási élettartamának végén jár, pl. magas a maradó alakváltozás aránya, vagy azért olyan, mert ilyen az aszfaltkeverék, de a maradó alakváltozás aránya kicsi. A pályaszerkezet méretezését mindenképpen ki kell egészíteni szubjektív állapotfelvétellel ill. további laboratóriumi vizsgálatokkal, ha szükséges.

$\mathrm{Az}$ „E” modulus nem állandó, még egy mérésen belül sem, de a hiba elfogadható mértékü, ha a teherbírás mérésekor a pályaszerkezeti rétegekben az adott körülmények mellett nem okozunk a rétegek törőfeszültségéhez közeli feszültséget.

Ha az út pályaszerkezetét elemi részekre bontjuk, amire az egyensúlyi egyenletek is vonatkoznak, akkor se a beton, se az aszfaltkeverék, se a talaj nem homogén és nem izotróp. Sőt, ha az elemi részeket, a standard atommodell szerint, elemi részecskéknek tekintjük, akkor az alkalmazott differenciálegyenletek peremfeltételei sehol se biztosítottak. Viszont, minél nagyobb léptékben vizsgálódunk, annál inkább teljesülnek a peremfeltételek.

Az aszfaltkeverék esetén, elemi szinten a feszültség terjed a kővázat alkotó kövön, ami szintén nem homogén, majd átadódik egy vékony bitumen filmre, onnan a bitumen habarcsra, esetleg közben vízre, vagy levegőre, ismét habarcsa, kőre stb. A feszültség terjedés ezek igen bonyolult kombinációja lesz, amely végül egy megfelelöen választott lépték esetében egy diszkrét érték felé halad.

A folyamat egy kicsit hasonlít a folyadék hőmérsékletéhez, ahol a hőt az elemi részecskék, molekulák kinetikai energiája adja. Ott sem lehet megadni egy részecske kinetikai energiáját, de azért 1 kg tömegü víz hőmérséklete jól mérhető, amely a részecskék kinetikai energiájának átlagából adódik.

Aszfaltkeverékek, betonok, sőt talajok esetén is legalább a keverék legnagyobb szemnagyságának kétszerese, háromszorosa kell legyen a megfelelő lépték.

A számítások során ennél sokkal kisebb léptéket is szoktunk választani, de tudni kell, hogy bár a számítás pontosabbnak tünik a lépték csökkentésével a számítás bizonytalansága rendkívül megnő egy konkrét vizsgálat esetén.

Ez azt jelenti, ha egy aszfaltgerendát hajlításnak teszünk ki, és mm-es pontossággal, meghatározott helyen kiszámítjuk a keletkező feszültségeket a gerenda szélétől, akkor garantáltan nagyot fogunk tévedni a konkrét vizsgálat és adott gerenda esetén ténylegesen kialakuló feszültségekhez képest. A feszültséget azonban nem mérjük, hanem számítjuk a megnyúlásból és a terhelő erőből, ez utóbbit se mérjük, csak számítjuk a gyorsulásból és a tömegből. A hajlított gerendán végzett feszültség számítása azért pontos, mert a hajlításból eredő megnyúlást viszonylag nagy tartományra vonatkozóan határozzuk meg. Hibás értéket kapnánk, ha a fajlagos megnyúlást 2-4 mm-en határoznánk meg, éppen egy kőszemcsén, de jó eredményt kapunk, ha a vizsgálati tartomány a legnagyobb szemnagyság 2-3-szorosa.

Ha nem egy konkrét keveréket vagy helyszínt vizsgálunk, akkor a minta darabszámának növekedésének arányában nő a pontosság is. A behajlásmérésnél egy konkrét hely tekintetében a mérés bizonytalan - az ismertetett okok miatt - és nem feltétlen a mérési módszer vizsgálati szórásának következtében. Vagyis egy hely teherbírása vonatkozó két mérés eltérése - rendkívül pontos mérési eljárás esetén is - 2-20\% is lehet. Sőt, ha a méröhellyel csak néhány cm-rel arrébb megyünk, ez az eltérés tovább fog növekedni.

Ha akár egy hosszabb vagy rövidebb útszakaszt akarunk jellemezni a mért teherbírással, akkor ehhez legalább 10-30 mérés szükséges, az elvárt megbízhatósági tartománytól függően, a szakasz hosszától azonban függetlenül.

Így, például, megbízhatóan jellemezhetünk egy 1000 m-es hosszúságú szakaszt 30 db méréssel, ha a pályaszerkezet rétegrendje, valamint az altalaj típusa és víztartalma se változik, de nem jellemezhetünk 
ugyanezen a szakaszon 100 m-t 2-3 mérésből megbízhatóan, mert az útpályaszerkezet inhomogenitása miatt túl nagy a szórás, ami kizárólag a mintaszám növelésével csökkenthető.

A víz példájára visszatérve, ha a víz molekuláinak nagysága közelítene az aszfaltkeverék ásványi vázának méretéhez, akkor a hőmérsékletet nem lehetne egy mérésből meghatározni, hanem a mért egység - nem lenne elég 1 kg-nyi víz - növelése mellett a mérések számát is növelni kellene és a mérőhelyeket is egyenletesen el kellene osztani az átlagos hőmérséklet elfogadható pontosságú számításához.

A gördülőkerekes mérések rendkívüli előnye éppen a nagy mérési számból adódik, még akkor is, ha a mérési módszer pontossága kisebb, mint más módszereké.

\section{A SZÁMÍTÁSI MÓDSZER GYAKORLATI HASZNA ÉS A MEGOLDANDÓ FELADATOK}

A módszerrel a behajlási teknő alapján és a pályaszerkezeti rétegek ismeretében rétegenként számítható a mérésre jellemző alakváltozási modulus.

Kiemelt fontosságú, hogy a méréskor a talajra vonatkozó alakváltozási modulust kitudjuk számolni a mért behajlási teknőből, így az útpályaszerkezet méretezésekor durva becslésként használt évszaki kiváltható.

A különböző módszerekkel mért behajlási teknők átszámíthatók, ha ismerjük a mérési módok terhelési sebességét és ismerjük anyagfajtánként, az aszfalt, a beton, a különböző talajok terhelési sebességtől függő alakváltozási modulusának változását.

A módszerrel jól modellezhető, bármilyen felületű és terhelésű eset és különböző rétegzettségü, tulajdonságú útpályaszerkezet által keletkezett behajlási teknő. A modellezett behajlási teknő görbületéből- pedig számíthatók a hajlításból eredő többlet feszültségek is.

A helyettesítő rétegvastagság egyszerü módosításával az is figyelembe vehető, hogy a hajlított rétegek elcsúsznak-e egymáson, vagy se.

A számítási modell nyújtotta lehetőségek kihasználásához az útpályaszerkezeti rétegek dinamikus viselkedését, a terhelés sebességétől függő mechanikai paraméterek (alakváltozási modulus, nyomószilárdság és húzószilárdság) változását sokkal jobban kellene ismerni, többek között meg kellene határozni az aszfaltkeverékek mestergöbéit [14] [15].

Az élettartam elemzéséhez a fáradási élettartam görbékre is szükség van minden aszfaltkeverék esetén, legalább megfelelő becslés szintjén.

Jelenleg az útpályaszerkezet méretezésekor a legnagyobb hibát az évszaki szorzó használatával követjük el, mert nem ismerjük a teherbírásmérés idején az altalaj pillanatnyi teherbírását, és ezért hibásan számítjuk át azt a méretezéskor használandó legkedvezőtlenebb „, $\mathrm{E}_{\mathrm{m}}$ ” méretési modulussá. Az elkövetett hiba nagyon nagy is lehet, akár a $100 \%$-ot is elérheti.

Szükséges a KUAB mérések és a tárcsás mérés összehasonlítása talajon, ahol a KUAB mérési eredményeknél nem a 0;200;300; 450 méréseket, hanem a 600; 900; 1200 méröpontokon kialakult behajlást kell figyelembe venni, ahol a KUAB terhelö erejét csökkenteni kell.

Nem elkerülhető a gördülökerekes és a KUAB párhuzamos méréssorozat végzése, különböző teherbírású útszakaszokon, ahol ismerjük az altalajt is. Ilyenek útszakaszok a régebben rendszeresen mért etalon szakaszok is.

\section{IRODALOMJEGYZÉK}

[1]: Boromissza, T., Gáspár, L., Károly, R. 2008: Útpályaszerkezetek teherbírása hazai és külföldi eredmények és problémák. Közúti és mélyépítési szemle 58. évfolyam, 2008/5-6. szám, pp. 1-9.

[2]: COST 324 Long Term Performance of Road Pavements, pp. 110-118.

[3]: Primusz, P., Tóth, Cs. 2020: Az egyedi pályaszerkezet-méretezésben rejlő gyakorlati előnyök. Aszfalt XXVII. évfolyam 2020/1 szám, pp. 12-19.

[4]: AASHTO: Mechanistic-Empirical Design of New \& Rehabilitated Pavement Structures

[5]: Gáspár, L., Horváth, F., Lublóy, L. 2011: Közlekedési létesítmények élettartama. UNIVERSITAS, pp.13-88. 
[6]: Nemedy, E. 1985: Útpályaszerkezetek méretezésének és anyagállandó-vizsgálatainak mechanikai alapjai. BME.

[7]: Zsichla, L. 1990: Development of the compulation of effective pavement deflection Highways and data processing, Paris, 13-15 mars 1990.

[8]: Zsichla, L. 1990: A mértékadó behajlás számítása mechanikai módszerrel. Közlekedésépítés- és mélyépítéstudományi szemle, 10. szám, pp. 370-375.

[9]: e-ÚT 06.03.13 Aszfaltburkolatú útpályaszerkezetek méretezése és megerősítése

[10]: Zsichla, L. 1990: Szakvélemény az M1-es autópálya 60,8-105,6 km közötti szakaszán építendő pályaszerkezetröl.

[11]: LTPP Characterizing Existing Asphalt Concrete Layer Damage for Mechanistic Pavement Rehabilitation Design. FHWA-HRT-17-059, 2018 pp. 130

[12]:https://pavementinteractive.org/reference-desk/pavement-management/pavementevaluation/deflection-based-nondestructive-pavement-analyses/

[13]: Zsichla, L. 1997: Aszfaltok komplex fáradási élettartamának meghatározása egyszerúsített módszerrel. Fővárosi Főpolgármesteri hivatal.

[14]: Tóth, Cs., Seoyoug, C., Primusz, P. 2020: A Ramberg-Osgood modell alakmazása az aszflattechnológiában. Útügyi lapok 8. évfolyam, 13. szám, https://doi.org/10.36246/UL.2020.1.06

[15]: LTPP Computid Parameter: Dynamic Modulus. FHWA-HRT-10-035, 2011. pp. 84-96 